AC 2009-651: DESIGN AND IMPLEMENTATION OF SCORING RUBRICS FOR TECHNICAL COURSES IN TWO-YEAR COLLEGES

Farzin Heidari, Texas A\&M University, Kingsville 


\title{
Design and Implementation of Scoring Rubrics for Technical Courses in Two-Year Colleges
}

\begin{abstract}
:
The process of assessment is to measure student performance. Instructors need to make sure that the assignments are scored as objectively as possible when evaluating a project. A rubric helps to set clear expectations and defines the quality of work for a given project. Descriptive scoring schemes have become a common method for evaluating course content. The descriptive scale supports the evaluation of the criteria set for each project. The focus of this paper is the design and implementation of scoring rubric models for technical courses in two-year colleges. The major points of this paper include identifying common definitions of assessment, identifying specific observable attributes in evaluating student performance, defining and brainstorming characteristics that describe each attribute, and the designing and implementation of scoring rubrics for a technical course. The following steps are involved in developing scoring rubrics: defining and listing learning objectives for technical courses, identifying the specific attributes that students should demonstrate in their performance, identifying each attribute and its characteristics, and identifying the excellent and poor quality work using narrative descriptive criteria. Holistic rubrics and analytical rubrics are both used to measures students understanding of course content. Holistic rubrics provide a choice to state the highest and lowest levels of performance combining the descriptors for all attributes and analytical rubrics state the highest and lowest levels of performance using the descriptions for each attribute separately. The use of rubrics allows the instructor to provide quality feed back to the student along with providing evaluation and reflection opportunities for an instructor as well. The use of rubrics in a technical program will provide accountability and evaluation that is beneficial to both students and college program.
\end{abstract}

\section{Introduction:}

Designing a valuable assessment to measure students' understanding of course content is both challenging and complicated. Especially, if designed prior to establishing clear course objectives, goals, and expectations. The purpose of assessments is to reinforce the accountability of both the student and instructor. This gives the student an opportunity to demonstrate their full potential, capacity, and ability to internalize, process, and apply the presented course content.

Furthermore, the instructor has provided an opportunity to process results and determine student strengths and weaknesses within the course. This is a beneficial instrument to generate purposeful feedback for students to recognize their misconceptions and reconceptualize these deficiencies within the course content. At the same time, instructors reevaluate their educational techniques and improve their effectiveness, to better steer students away from common misconceptions. The technical college instructors can take this evaluation piece a step further by incorporating the rubric.

The purpose of the rubric is to outline the assessment's expectations with required course related details. Typically, a rubric assigns a score range based on student performance of 
outlined expectations. Curriculum experts believe that educators who design rubrics will be more effective educators. Instructors will be compelled during the evaluation process to think meticulously about generating, successful student outcome. The technical college instructors know what they are going to teach, facilitate, and evaluate to ensure students benefit from technical courses. Incorporating scoring rubrics to technical course assessments are one way to evaluate student's responses to performance assessments. Both analytical and holistic scoring rubrics can be used to evaluate technical courses. Once the performance assessments, with accompanying scoring rubrics are designed, the coursework objectives are facilitated, to prepare students for the upcoming assessment administered. Utilizing rubrics increases both instructors' and students' accountability for student learning with the accountability of the program. The technical college program is required by regional and professional accrediting agencies to prepare students for the technical work force. Designing and implementing a systematic technical course evaluation is beneficial to technical college students and programs.

\section{Scoring Rubrics:}

Educators design the scoring rubric with a descriptive format that evaluates and determines the students' performance based on required criteria to meet course content goals. Scoring rubrics will define the required effort, quality, and judgment necessary to master a technical objective. Foundational skills and content knowledge are required to write a G-code program for a Computer Numerical Control (CNC) machine. This performance objective can be evaluated using scoring rubrics. The score ranges are based on descriptive scales that reflect the students' mastery level of the set criteria. Rubrics provide two benefits in the evaluation process of a technical course. First, they support the degree of accomplishments and the extent to which specific criteria has been mastered. Second, they provide feedback to students with suggestions to improve on their performance.

\section{Different Types of Scoring Rubrics:}

Several different types of scoring rubrics are available. Two widely used types of rubrics are analytical and holistic. Holistic rubrics are more appropriate when there is no definitive correct answer. Holistic scoring rubrics support broader judgments concerning the quality of the process or product. For example the ability to use and apply a canned-cycle-drilling operation within a G-code program is an example of a Holistic scoring rubric. Utilizing holistic rubrics incorporates more structure into the evaluation technique with efficient results in the scoring process. Analytical rubrics are usually preferred when response engages student to focus on a more specific task. For example, the students are required to understand and achieve mastery to create a G-code program with function codes, miscellaneous codes, $\mathrm{X}$ and Y positioning, block sequence, and linear and circular interpolation. This type of rubric allows for separate evaluative criteria to be scored using various descriptive scales. Analytical scoring rubrics generate a significant amount of feedback to offer students.

\section{Steps in Developing Scoring Rubrics:}

The first step in developing a scoring rubric is to identify the technical skills and content knowledge necessary to assess student proficiency on course objectives. Next we evaluate the 
desired outcome from the assessment and determine to use analytical or holistic scoring rubrics. Both the top level performance and lowest level of performance criteria should be defined by the evaluator. The contrast between the top level performance criterion and bottom level performance criterion will help to write the criterion for middle level performance. The following steps involved to develop scoring rubrics:

1. Define and list learning objectives for a technical course.

2. Identify the specific attributes that students should demonstrate in their performance.

3. Identify each attribute and its characteristics.

4. Identify excellent versus poor work using narrative descriptive criteria.

5. For holistic rubrics, state the highest and lowest levels of performance combining the descriptors for all attributes.

6. For analytical rubrics, state the highest and lowest levels of performance using the descriptions for each attribute separately.

7. Collect student work and record the results.

8. Update and revise the rubric as necessary.

\section{Holistic Scoring Rubric G-Code Programming}

\section{Points}

G-Code program is correct and functional contains sub-programs and verifies perfectly. Consistently does all of the following:

- The program is sequential has correct feed, speed and it starts and ends correctly.

- One or more sub-programs integrated into the main program and the whole program verifies perfectly.

- Liner-Interpolation, circular interpolation, and rapid travers are used in the program to generate the part.

- Multiple tool option is used in the program and it verifies correctly.

- The program is able to machine a complicated part rapidly.

\section{Points}

G-Code program is correct and functional but does not contain a sub-program. Does most or many of the following:

- The program is sequential, has correct feed and speed, and it starts and ends correctly.

- Linear-Interpolation, circular interpolation and rapid travers are used in the program to generate the part.

- Sub-program is not used.

- Multiple tool option is sued in the program and it verifies correctly.

- The program is able to machine a complicated part.

\section{Points}

G-code program is simple and only creates straight cut and is not able to create circular cuts. Does most or many of the following:

- The program is sequential has correct feed and speed and it starts and ends correctly.

- Only linear interpolation and rapid travers are used in the program to generate a 
simple part.

- Sub-program option is not used.

- Only single tool option is used in the program

- The program is able to machine and verify a simple part.

\section{Point}

G-code program is simple and partly functional. The program is not ready to be used by a CNC machine. Consistently does all of the following.

- The program verifies but it is not complete and misses some steps or cuts.

- Liner interpolation and rapid travers are miss-used in the program.

- The program generates an error message when it is verified.

- The program needs to be edited before it can be verify and generate a simple part.

Figure 1: Holistic Scoring Rubric for G-code Programming

\begin{tabular}{|c|c|c|c|c|c|}
\hline \multicolumn{6}{|c|}{$\begin{array}{c}\text { Analytical Scoring Rubric } \\
\text { G-Code Programming }\end{array}$} \\
\hline Criteria & $\begin{array}{c}\text { Beginning } \\
1\end{array}$ & $\begin{array}{c}\text { Developing } \\
2\end{array}$ & $\begin{array}{c}\text { Accomplished } \\
\mathbf{3}\end{array}$ & $\begin{array}{c}\text { Exemplary } \\
4\end{array}$ & Score \\
\hline $\begin{array}{l}\text { Understanding } \\
\text { of program } \\
\text { structure and } \\
\text { G and M } \\
\text { codes. }\end{array}$ & $\begin{array}{l}\text { Simple } G \text { and } \\
\text { M codes are } \\
\text { used in the } \\
\text { program. The } \\
\text { program is } \\
\text { simple, } \\
\text { sequential but } \\
\text { not } \\
\text { functional. }\end{array}$ & $\begin{array}{l}\text { Simple G } \\
\text { and M codes } \\
\text { are used in } \\
\text { the program. } \\
\text { The } \\
\text { program is } \\
\text { simple, } \\
\text { sequential } \\
\text { and } \\
\text { functional. }\end{array}$ & $\begin{array}{l}\text { Some advance } \\
\mathrm{G} \text { and } \mathrm{M} \\
\text { codes are used } \\
\text { in the } \\
\text { program. The } \\
\text { program is } \\
\text { sequential, } \\
\text { correct and } \\
\text { functional. }\end{array}$ & $\begin{array}{l}\text { All the } \\
\text { advanced } \mathrm{G} \\
\text { and } \mathrm{M} \text { codes } \\
\text { are used in the } \\
\text { program. The } \\
\text { program is } \\
\text { complex } \\
\text { sequential, } \\
\text { correct and } \\
\text { functional. }\end{array}$ & \\
\hline $\begin{array}{l}\text { Use of rapid } \\
\text { traverse, } \\
\text { linear- } \\
\text { interpolation } \\
\text { and circular } \\
\text { interpolation } \\
\text { in the } \\
\text { program. }\end{array}$ & $\begin{array}{l}\text { The program } \\
\text { contains only } \\
\text { rapid traverse } \\
\text { and linear } \\
\text { interpolation. } \\
\text { It is not able } \\
\text { to make any } \\
\text { circular } \\
\text { interpolations. }\end{array}$ & $\begin{array}{l}\text { The } \\
\text { program } \\
\text { contains } \\
\text { rapid } \\
\text { traverse, } \\
\text { linear } \\
\text { interpolation } \\
\text { and is only } \\
\text { able to } \\
\text { create arcs. }\end{array}$ & $\begin{array}{l}\text { The program } \\
\text { contains rapid } \\
\text { traverse, linear } \\
\text { interpolation } \\
\text { and is able to } \\
\text { create arcs and } \\
\text { full circles. }\end{array}$ & $\begin{array}{l}\text { The program } \\
\text { contains rapid } \\
\text { traverse, linear } \\
\text { interpolation is } \\
\text { able to create } \\
\text { arcs and full } \\
\text { circles. A } \\
\text { subprogram is } \\
\text { used to create } \\
\text { multiple arcs } \\
\text { or circles. }\end{array}$ & \\
\hline $\begin{array}{l}\text { Use of } \\
\text { advanced } \\
\text { features } \\
\text { including sub- } \\
\text { program, } \\
\text { canned- }\end{array}$ & $\begin{array}{l}\text { The program } \\
\text { is simple and } \\
\text { only uses the } \\
\text { milling } \\
\text { function. }\end{array}$ & $\begin{array}{l}\text { The } \\
\text { program } \\
\text { does not } \\
\text { contain any } \\
\text { canned- } \\
\text { cycle for }\end{array}$ & $\begin{array}{l}\text { The program } \\
\text { contains a } \\
\text { canned-cycled } \\
\text { drill function } \\
\text { and it creates } \\
\text { rows of same }\end{array}$ & $\begin{array}{l}\text { The program } \\
\text { contains sub- } \\
\text { program to } \\
\text { create a pocket } \\
\text { operation. A } \\
\text { canned-cycled }\end{array}$ & \\
\hline
\end{tabular}




\begin{tabular}{|c|c|c|c|c|}
\hline $\begin{array}{l}\text { cycles, and } \\
\text { multiple tool } \\
\text { options in the } \\
\text { program. }\end{array}$ & & $\begin{array}{l}\text { drilling but } \\
\text { is able to } \\
\text { change } \\
\text { cutter from } \\
\text { milling to } \\
\text { drilling } \\
\text { cutter and is } \\
\text { able to drill } \\
\text { few holes }\end{array}$ & $\begin{array}{l}\text { size holes. } \\
\text { The program } \\
\text { pauses and } \\
\text { allows the } \\
\text { machine to } \\
\text { change the } \\
\text { cutter from } \\
\text { milling to } \\
\text { drilling. }\end{array}$ & $\begin{array}{l}\text { is used to } \\
\text { create rows of } \\
\text { different size } \\
\text { holes. The } \\
\text { program } \\
\text { pauses and } \\
\text { allows the } \\
\text { machine to } \\
\text { change cutter } \\
\text { many times. }\end{array}$ \\
\hline $\begin{array}{l}\text { Program } \\
\text { writing skills } \\
\text { and part } \\
\text { generation } \\
\text { complexity is } \\
\text { evident. }\end{array}$ & $\begin{array}{l}\text { The program } \\
\text { contains } \\
\text { linear cuts } \\
\text { only and it } \\
\text { produces a } \\
\text { simple } \\
\text { engraving. }\end{array}$ & $\begin{array}{l}\text { The } \\
\text { program } \\
\text { contains } \\
\text { linear cuts, } \\
\text { arcs, and } \\
\text { circles. It } \\
\text { produces a } \\
\text { simple part. }\end{array}$ & $\begin{array}{l}\text { The program } \\
\text { contains linear } \\
\text { cuts, arcs, } \\
\text { circles and } \\
\text { drill function. } \\
\text { It produces a } \\
\text { functional } \\
\text { part. }\end{array}$ & $\begin{array}{l}\text { The program } \\
\text { contains text, } \\
\text { linear cuts, } \\
\text { arcs, circles } \\
\text { pockets, and } \\
\text { drill function. } \\
\text { It produces a } \\
\text { functional part. }\end{array}$ \\
\hline
\end{tabular}

Figure 2: Analytical Scoring Rubric for G-Code Programming

\section{Conclusion:}

An informative assessment is the process of measuring educational effectiveness with comparisons to a set of standards, goals and objectives. Scoring rubrics use a descriptive scoring format that develops a common thread for evaluation process of technical courses. Rubrics are a motivating tool for students, feeding them the necessary confidence to meet required expectations outlined within the mastery levels. The feedback encourages students to inquire why they received the score they earned and improve their overall performance.

\section{References:}

Airasian, P. W. (2001). Classroom Assessment: Concepts and Applications (4 $4^{\text {th }}$ ed.) Boston: McGraw-Hill

Mertler, C. A. (2003). Designing Scoring Rubrics for Your Classroom. Practical Assessment, Research, \& Evaluation , 7 (25). Available online: http://pareonline.net/getun.asp?v=7\&n=3.

Chase, C. I. (1999) Contemporary Assessment for Educators New York: Longman.

Moskal, B. M. (2000). Scoring Rubrics: What, When, and How? Practical Assessment, Research, \& Evaluation, 7(3). Available online: http://pareonline.net/getun.asp?v=7\&n=3 